\title{
POLA HERMENETIK SASTRA HIKMAT ORANG IBRANI
}

\author{
Sonny Eli Zaluchu \\ Pascasarjana Sekolah Tinggi Teologia Baptis Indonesia (STBI) Semarang \\ Jln. Simongan No. 1 Pusponjolo Selatan - Semarang 50141 - Jateng - Indonesia \\ Email: sonnyzaluchu@stbi@ac.id
}

\begin{abstract}
Sonny Eli Zaluchu, The Hermenetic Pattern of Hebrew Wisdom Literature. Hebrew Wisdom Literature is one of the most distinctive kinds of literature that can found in the Old Testament. Particular hermeneutic patterns are needed to interpret literary books. The writings of the wisdom literature of the Hebrew people are rich in various types of literary styles from being oral traditions to written forms and being part of the Old Testament canon. This paper aims to form a hermeneutic pattern in the form of defining literary categories, capturing the main ideas of the writer, seeing the text in context, and paying attention to the style of language. Studying these four patterns will help the interpreter elevate the meaning of the contents of the literature of Wisdom. Writing presented in a descriptive, analytical form.
\end{abstract}

Key Words: Wisdom Literature, Hermeneutics, Old Testament Methods

\begin{abstract}
Abstrak: Sonny Eli Zaluchu, Pola Hermenetik Sastra Hikmat Orang Ibrani. Sastra Hikmat Orang Ibrani adalah salah satu sastra yang sangat khas yang dapat dijumpai di dalam Perjanjian Lama. Diperlukan pola hermenetik khusus untuk melakukan penafsiran terhadap kitab-kitab sastra tersebut. Hal tersebut diperlukan karena tulisan sastra hikmat orang ibrani kaya dengan berbagai jenis gaya kesusasteraan sejak menjadi tradisi oral hingga dalam bentuk tertulis dan menjadi bagian dari kanon Perjanjian Lama. Tulisan ini bertujuan merumuskan pola hermenetik berupa menentukan kategori sastra, menangkap gagasan utama penulis, melihat teks di dalam konteks, dan memperhatikan gaya bahasa. Mempelajari keempat pola tersebut akan menolong penafsir mengangkat makna dari isi kitab-kitab sastra Hikmat. Tulisan disajikan di dalam bentuk deskriptif analitis.
\end{abstract}

Kata Kunci: Sastra Hikmat Orang Ibrani, Hermenetik, Metodologi Perjanjian Lama

\section{PENDAHULUAN}

Salah satu persoalan pelik menyangkut kitabkitab hikmat, menurut penelitian Zaban, adalah tampilnya kitab-kitab itu dalam bahasa metafora yang harus diterjemahkan ke dalam konteks kontemporer. Analisis terhadap metafora-metafora tersebut menolong di dalam proses interpretasi (Zabán, 2016). Apalagi dalam sudut pandang Renn, kitab hikmat itu berkorelasi dengan sudut pandang kehidupan dari sisi Tuhan, membuatnya menjadi tidak mudah ditafsirkan (Renn, 2005, p. 1050). Fakta yang lain adalah menyangkut kredibilitas sastra. Orang-orang Ibrani kuno dikenal sebagai guru hikmat terbaik di kawasan Timur Tengah. Pada masa Perjanjian Lama, bukan saja Imam dan Nabi, orang-orang berhikmat menjadi tujuan kaum awam untuk meminta petunjuk, nasihat dan keputusan atas perkara tertentu. Itulah sebabnya dikatakan, hikmat adalah kemampuan atau kecakapan atau juga disebut keahlian yang dimiliki orang-orang tertentu untuk melakukan sesuatu secara benar, dan tepat, baik dari sudut pandang waktu maupun dilihat dari konten masalah yang ada. Melaluinya, kehidupan berjalan dengan lebih baik dan menjawab masalah-masalah yang ada. Walaupun penafsirannya sulit, tetapi sifatnya sangat praktis. Temuan Knut menyangkut Amsal 26:1-12 misalnya, membuktikan betapa tidak mudahnya menafsirkan Kitab Amsal. Di dalam perikop itu Knut berhasil membuktikan adanya strategi editorial yang disengaja oleh penulis yang memaksa penafsir modern merumuskan cara khusus hermenetik kitab tersebut (Knut, 2010).

Ditilik dari sumbernya, literatur hikmat adalah sebuah proses panjang dari tradisi oral hingga menjadi sebuah naskah. Itulah yang menyebabkannya penuh dengan berbagai gaya sastra. Di Asia Ba- 
rat kuno, gaya sastra ini menjadi sesuatu yang lazim dan ditemukan di dalam banyak karya (Douglas, 2005, p. 393). Lima kitab di dalam Perjanjian Lama kanonik, Ayub, Amsal, dan Pengkhotbah, dan ditambahkan oleh beberapa ahli seperti Kidung Agung dan Mazmur diidentifikasi sebagai kitab-kitab yang di dalamnya selain sebagai kitab puisi, juga merupakan sastra hikmat. Dua karya Perjanjian Lama non kanonik ikut serta dalam kelompok ini yaitu Apokrifa Sirakh dan Kebijaksanaan Salomo.

Contohnya Salomo, yang dipandang sebagai salah satu guru hikmat yang terbesar di dalam sejarah teks Perjanjian Lama. Ketika naik ke tahta dan meneruskan kepemimpinan Daud, raja muda ini tidak meminta kekayaan dan kekuasaan atau kemenangan atas musuh. Salomo justru meminta hikmat kepada Allah agar mampu menjalankan pemerintahan yang baik dan benar. Dituliskan di dalam 1 Rajaraja 3:9 permintaan Salomo kepada Allah,

Maka berikanlah kepada hamba-Mu ini hati yang faham menimbang perkara untuk menghakimi umat-Mu dengan dapat membedakan antara yang baik dan yang jahat, sebab siapakah yang sanggup menghakimi umat-Mu yang sangat besar ini?

Respon Allah melebih hal yang diminta Salomo. Selain memberikan hikmat, Salomo mendapat bonus kekayaan dan kemuliaan. 1 Raja-raja 4:29-34 mencatat, "Dan Allah memberikan kepada Salomo hikmat dan pengertian yang amat besar, serta akal yang luas seperti dataran pasir di tepi laut, sehingga hikmat Salomo melebihi hikmat segala bani Timur dan melebihi segala hikmat orang Mesir. Ia lebih bijaksana dari pada semua orang, dari pada Etan, orang Ezrahi itu, dan dari pada Heman, Kalkol dan Darda, anak-anak Mahol; sebab itu ia mendapat nama di antara segala bangsa sekelilingnya. Ia menggubah tiga ribu amsal, dan nyanyiannya ada seribu lima. Ia bersajak tentang pohon-pohonan, dari pohon aras yang di gunung Libanon sampai kepada hisop yang tumbuh pada dinding batu; ia berbicara juga tentang hewan dan tentang burung-burung dan tentang binatang melata dan tentang ikan-ikan. Maka datanglah orang dari segala bangsa mendengarkan hikmat Sa- lomo, dan ia menerima upeti dari semua raja-raja di bumi, yang telah mendengar tentang hikmatnya itu." Perhatikan catatan tersebut, Salomo menyampaikan karya oral dan menulis banyak amsal, nyanyian dan sajak. Kesimpulan Derek Kidner patut diperhitungkan. Dari semua reputasi mengenai hikmat di dalam Perjanjian Lama, hikmat Salomolah yang paling unggul, sebab hikmat yang dimilikinya itu bukan semata-mata bergantung dari kecerdasannya sendiri tetapi didukung oleh sifatnya yang gemar belajar dan kemampuan dalam hal seni (Handbook to the Bible, 2004, p. 356). Geord Fohrer dalam karya klasiknya berargumentasi, masuknya kitab-kitab ke dalam kelompok Sastra Hikmat disebabkan oleh kandungan ajaran ajaran yang dimilikinya, sehingga seseorang menjalani hidup dengan hati-hati, penuh pertimbangan, berkompeten untuk menaklukan dunia dan segala permasalahan-permasalahan hidup (Kittel, 1971, p. 476).

Melihat sifat naskah yang sangat kaya dan dalam dengan berbagai gaya kesusateraan, sejak muncul di dalam tradisi oral hingga menjadi teks tertulis Alkitab, hermenetik Sastra Hikmat adalah sebuah tantangan bagi para teolog komtemporer. Roberge mengatakan perlunya konsep critical hermeneutics untuk mengangkat makna kitab-kitab itu dan menjembatani ke dunia komtemporer (Roberge, 2011). Menarik untuk diselidiki secara teoritis, model dan pendekatan hermenetik apakah yang sesuai untuk tujuan tersebut. Itulah yang menjadi tujuan artikel ini.

\section{METODE}

Metode yang dipakai adalah pendekatan kualitatif melalui analisis deskriptif analitik. Pertamatama penulis memberikan deskripsi tentang Sastra Hikmat Orang Ibrani, tokoh-tokoh sentral dan ciri utamanya untuk memberikan gambaran tentang eksistensi kitab tersebut. Kemudian dilanjutkan dengan analisis kitab menurut bentuk sastra, hingga mengarah pada pola hermenetik yang tepat sesuai bentuk dan struktur kitab. Untuk melengkapi pembahasan, penulis melakukan kutipan teks langsung ke dalam pembahasan. 
Pendekatan yang sama juga dipergunakan di dalam memahami isi kitab berdasarkan alam berpikir penulisnya dan gaya kesusasteraan yang dipakai oleh penulis. Disini penulis menggunakan metode diakronik dengan pertimbangan, pembentukan seluruh kitab Sastra Hikmat lahir dari tradisi Israel kuno, dengan tetap mengakui bahwa sejumlah karya sastra tersebut tidak memiliki urutan logis (Koller, 2012).

Pengembangan analisis dilakukan dengan melihat struktur sastra dari teks-teks tersebut walaupun tidak mengambil seutuhnya sebagaimana pendekatan kritik bentuk. Hal ini dilakukan untuk mendapatkan tipikal kesusasteraan yang dipergunakan penulis Ibrani kuno di dalam teks sehingga penafsir dapat memperoleh konteks teologis dari tulisan tersebut (Goldsworthy, 2011). Gaya sastra hikmat dan puisi, di dalam kitab-kitab tersebut dengan sendirinya telah menjadi kunci hermenetik penafsiran kitab-kitab tersebut (Notarius, 2011).

\section{HASIL DAN PEMBAHASAN}

Pembahasan dimulai dengan memaparkan tujuan dari sastra hikmat, ciri khasnya serta bentuk kesusasteraannya yang dipakai para penulisnya. Ketiga hal tersebut memberi jalan untuk menyusun pola bagi hermenetik.

\section{Tujuan Sastra Hikmat}

Tujuan utama karya sastra hikmat orang Ibrani adalah ajaran untuk hidup berhasil dan permenungan tentang eksistensi manusia (Douglas, 2005, p. 393; Fox, 2007). Permenungan ini dapat mencakup peran manusia di dalam kehidupannya secara pribadi, hubungannya dengan sesama dan terlebih, relasinya dengan Tuhan sang pencipta serta usaha untuk menikmati hidup di dalam alam ciptaan-Nya dengan sukacita menurut peraturan-peraturan-Nya. Rumusan Osborne sangat menegaskan hal tersebut. Hikmat bertujuan untuk menggunakan ciptaan Allah dengan tepat dan untuk menikmati hidup sekarang di bawah pemeliharaan-Nya (Osborne, 2012, p. 283). Itu sebabnya Osborne mendefinisikan hikmat sebagai menghidupi kehidupan di dunia Allah dengan peraturan Allah. Osborne beralasan, pusat dari tulisan-tulisan hikmat bukanlah kehidupan sekuler melainkan mengusung tema takut akan Allah (Osborne, 2012, p. 283).

Desmond melengkapinya dengan membagi tiga kelompok hikmat bangsa Ibrani menurut kegunaannya. Pertama, Perceiving Wisdom. Hikmat ini berguna untuk memahami dunia dimana manusia hidup dan beraktifitas. Kedua, Action-related Wisdom. Hikmat jenis ini berguna untuk melakukan segala sesuatu berdasarkan persepsi yang benar, menyangkut perilaku yang benar dalam kehidupan sehari-hari. Ketiga, Communicating Wisdom. Hikmat yang digunakan untuk belajar-mengajar, menasihati dan mengevaluasi tindakan orang lain (Alexander, Rosner, Carson, \& Goldsworthy, 2000, p. 843).

\section{Ciri Sastra Hikmat Orang Ibrani}

Osborne mengelompokkan empat kategori sastra orang Ibrani berdasarkan fungsinya di dalam kehidupan dan paradigma orang Israel (Osborne, 2012, pp. 284-289). Adamo mendukung beberapa hal pendapat Osborne tersebut (Adamo, 2015). Pertama, sifat hikmat yang memiliki orientasi praktis. Dalam sifat ini, hikmat pada umumnya diarahkan untuk menjawab tantangan dan persoalan kehidupan secara pragmatis. Meliputi tata krama, hubungan sosial, hubungan kekeluargaan, penguasaan diri, etos kerja, dan sebagainya. Kedua, sifat hikmat yang menjelaskan ketergantungan kepada Tuhan. Tema sentral dari hikmat adalah membawa pembacanya memiliki ketergantungan kepada Allah secara mutlak. Dengan demikian, hikmat orang ibrani memiliki sifat religius melampauhi kesusasteraan Timur Dekat kuno yang lebih pada unsur sekuler. Para penyair Ibrani membawa sastra mereka kepada pengagungan dan penhormatan YAHWEH. Ketiga, sifat hikmat yang mengandung otoritas. Kendatipun dirasakan bahwa hikmat bukan merupakan sebuah pewahyuan langsung seperti dinyatakan kepada para nabi-nabi di dalam Perjanjian Lama, hikmat memainkan peranan untuk menyatakan otoritas tidak langsung ke dalam kehidupan manusia melalui orang-orang bi- 
jaksana yang menyebarluaskan hikmat itu sebagai sintesis dari ketiga hal penting: Allah, tradisi dan pengalaman hidup. Keempat, sifat hikmat yang berkaitan dengan penciptaan. Hikmat Perjanjian Lama harus dilihat dalam frame teologi penciptaan. Sastra hikmat diarahkan untuk mereposisi kehidupan manusia di dalam kerangka penciptaan yang harmonis dan indah. Dalam hal ini manusia harus memaknai dirinya di dalam tatatan pengaturan Allah.

Kategori yang dikemukakan oleh Leeuwen sedikit berbeda dari pendapat Osborne di atas. Menurutnya ada empat natur utama dari karya sasta hikmat orang Ibrani (Leeuwen, 2005, pp. 847-850). Pertama, hikmat berawal dari sikap takut akan Tuhan. Contohnya kitab Amsal. Frasa 'takut akan Tuhan' bukan hanya dimulai di dalam Amsal 1:7 (Takut akan TUHAN adalah permulaan pengetahuan, tetapi orang bodoh menghina hikmat dan didikan). Frasa ini bahkan muncul lebih dari tiga belas kali di dalam keseluruhan Amsal dan menjadi salah satu faktor kunci isi kitab tersebut. Semua ini merupakan cerminan hubungan Israel dengan YAHWEH. Dengan kata lain, apapun bentuk dan pesan hikmat, penekanan utamanya adalah membawa orang memiliki kehidupan yang takut akan Tuhan. Kedua, mirip dengan pekenanan Osborne, Leeuwen mengatakan bahwa hikmat harus dilihat dan diterima sebagai gaya hidup di dalam kerangka penciptaan Allah. Dalam hal ini hikmat membawa orang untuk memahami kedudukan Allah sebagai pencipta dan hakim atas seluruh ciptaan. Manusia berada di dalam hukum dan pengaturan Allah. Pandangan ini bertolak belakang dengan hikmat Timur Dekat yang memberi penekanan pada tatanan dunia dan kekuatan systemnya. Hikmat orang Ibrani melampauhi tatanan dunia, dimana hanya hikmat dari Allah saja yang mampu mengarahkan manusia di dalam cara hidup yang benar di dalam dunia ini, menjadi bagian dari ciptaan dan memelihara ciptaan itu untuk kemuliaan nama-Nya. Leeuwen menyebutkan ini dengan istilah Biblical Wisdom. Ketiga, hikmat membentuk tatanan kehidupan yang jauh lebih baik dalam kehidupan manusia, baik secara pribadi, komunal maupun di dalam keluarga. Lebih kepada prinsip guidance sehingga manusia memiliki standar hidup dan pengambilan keputusan yang tepat. Dan yang keempat, hikmat didasarkan pada tradisi. Ini pendekatan yang benar-benar baru di dalam pengelompokkan hikmat. Tradisi selalu diteruskan dan diturunkan dari satu generasi ke generasi. Dengan menurunkan tradisi, sistem nilai di dalam angkatan yang baru akan tetap terjaga dan terpelihara. Hikmat bahkan ikut menjadi dan membentuk tradisi itu sendiri.

Dari penjelasan Osborne dan Leeuwen dapat ditarik kesimpulan bahwa ciri sastra hikmat orang Ibrani paling tidak menyangkut spesifikasi berikut ini: 1) Memimpin pada hidup yang Takut akan Tuhan; 2) Mendorong untuk tetap di dalam Tuhan; 3) Menekankan pentingnya ketaatan; 4) Memberikan nilai-nilai kebenaran; 5) Memaparkan solusi solusi praktis dalam menjalani hidup; 6) Mendorong untuk menjadi orang baik dan menjauhi kejahatan; 7) Menekankan bahwa hikmat yang utama adalah dari Tuhan; 8) Mengarahkan pada kehidupan sosial yang baik; 9) Membangkitkan kesadaran bahwa Tuhan adalah pencipta segalanya

\section{Bentuk-bentuk Sastra Hikmat Orang Ibrani}

Hikmat orang Ibrani sebagai sebuah karya sastra memiliki sejumlah bentuk. Dari bentuk bentuk inilah dapat dikenali bagian-bagian mana di dalam Ayub, Amsal, Pengkhotbah dan sebagian Mazmur serta Kidung Agung, yang tergolong dalam sastra hikmat (Gaebelein, 1991). Di pihak lain, bentuk kesusasteraan menolong penafsir menangkap arah dan tujuan teks di dalam naskah. Secara umum, bentuk bentuk sastra hikmat Ibrani dikategorikan sebagai berikut:

\section{Berbentuk Amsal}

Amsal diterjemahkan dari kata Ibrani 'masal' adalah bentuk paling lazim dalam sastra hikmat Ibrani. Bahkan, amsal-amsal yang berupa kitab di dalam Perjanjian Lama sebagian besar dibentuk oleh muatan hikmat. Titik tolaknya adalah hasil pengamatan terhadap fenomena alam dan budaya dibawa 
ke dalam tatanan kehidupan, baik di dalam berkeluarga maupun di dalam bermasyarakat (Gertz, Berlejung, Schmid, \& Witte, 2017, p. 671). Kontennya bersifat singkat dan kebenarannya diterima secara universal. Formulasinya mudah diingat. Pada awalnya ini adalah sastra oral yang kemudian dikumpulkan dan dibuat tertulis. Ditambahkan oleh Klein, secara tata bahasa sebuah amsal ditulis dalam bentuk mode indikatif sehingga tampil sebagai sebuah deklarasi sederhana dan apa adanya tentang kehidupan (Klein, Blomberg, \& Hubbard, 2013, p. 312). Selain itu, Klein menambahkan bahwa isinya dapat deskriptif, memberi petunjuk, menyatakan perbandingan dan mengungkapkan sesuatu yang bersifat antitesis (Klein et al., 2013, pp. 312-314).

\section{Sebagai Sebuah Cerita Contoh dan Refleksi}

Amsal ini merupakan bagian dari pernyataan empirik karena berasal dari pengalaman seseorang dan kemudian mendapatkan kebenaran dari pengalaman tersebut. Amsal berisi refleksi atas kejadian atau peristiwa tertentu. Melalui refleksi sebuah kebenaran dihasilkan dan menjadi pelajaran bagi pendengar atau pembaca. Dapat ditemukan misalnya di dalam Pengkhotbah 1:12.

\section{Merupakan Ucapan}

Ucapan di dalam sastra hikmat oleh Murphy dibagi dua. Pertama ucapan berdasarkan pengalaman dan kedua ucapan didaktik untuk mendidik dan memastikan suatu nilai khusus diterapkan (Murphy, 1982, pp. 4-5). Ada beberapa jenis ucapan di dalam sastra hikmat yakni: Ucapan-ucapan perdebatan atau dikategorikan sebagai sebuah dialog - menyampaikan perdebatan atas situasi atau topik tertentu (Ayb. 2:8-10); Ucapan-ucapan berkat (Mzm. 1:1); Ucapan pengajaran dan didikan (Ams. 8:33); Penuturan atau Ucapan Hikmat (Ams. 9:1-6); Ucapan pribadi atau monolog (Ayb. 17:1-16)

\section{Berupa Himbauan dan Nasihat}

Bertujuan untuk menguatkan tindakan seseorang atau menasihati untuk mengikuti anjuran ter- tentu sehingga kualitas hidupnya berubah menjadi lebih baik. Hikmat digunakan untuk memotivasi seseorang dan menyerahkan pilihan ke dalam tangannya. Dapat disampaikan secara positif maupun negatif. Contohnya Amsal 9:9, berilah orang bijak nasihat, maka ia akan menjadi lebih bijak, ajarilah orang benar, maka pengetahuannya akan bertambah. Semua kategori intrintik dari Amsal masuk ke dalam 'himbauan dan nasihat'.

\section{Merumuskan Pola Hermenetik Sastra Hikmat}

Sebagai bagian dari kitab Suci, pola hermenetik umum dapat diterapkan pada kitab-kitab Hikmat. Akan tetapi, perlu ada pendekatan hermenetik khusus menyangkut pola kesusasteraan kitab-kitab tersebut (Dell, 2006). Naskah-naskha sastra hikmat berbeda dari naskah kitab suci lainnya. Naskah sastra hikmat sangat kaya dengan berbegai bentuk kesusasteraan yang tidak dapat didekati sebagaimana naskah sejarah, narasi sebagaimana kitab-kitab lainnya (Gaebelein, 1991). Berikut ini adalah rumusan pola yang diusulkan.

\section{Menentukan Kategori Sastra}

Sastra hikmat sebagai sebuah genre, memiliki sejumlah sub kategori yang mencirikan jenis hikmat itu sendiri. Itu sebabnya, langkah pertama untuk menafsirkan sastra hikmat orang Ibrani adalah menentukan kategori sastra tersebut, apakah tergolong amsal, pengajaran, refleksi, ucapan, himbauan/nasihat atau alegori.

Amsal misalnya, poin poin penting yang diungkap didalamnya bukanlah kebenaran mutlak. Melainkan sebuah kemungkinan yang mengarahkan dan membentuk perilaku dan memberikan pilihan, jika melakukannya akan mengarahkan hidup menjadi lebih baik. Dengan kata lain penafsir harus melihat amsal sebagai paparan prinsip-prinsip hidup yang praktis daripada sebuah legalitas hukum. Bisa jadi, sebuah amsal dapat menjadi inspirasi pada satu persoalan atau fakta tetapi tidak tepat jika diterapkan pada situasi lain yang mirip. Termasuk isinya, amsal seringkali menyatakan sesuatu dengan cara yang ber- 
tolak-belakang dari maksud sebenarnya. Oleh sebab itu, ekspresi kebenaran yang diungkapkan di dalam sebuah amsal, haruslah ditafsirkan secara komprehensif dengan melihat sifat-sifat amsal itu sendiri.

Apabila sebuah sastra hikmat disampaikan di dalam bentuk pengajaran, maka penafsir harus menangkap terlebih dahulu motif apa yang hendak diungkap di dalam pengajaran tersebut. Beda dengan amsal yang hanya memberikan alternatif, pengajaran menuntut respon dan disampaikan secara imperatif (tidak punya pilihan kecuali menaatinya). Pengajaran mengarah pada sesuatu hal yang dituntut harus diperbaiki, dirubah atau dilakukan demi tujuan yang baik. Biasanya terdapat hal-hal tertentu di dalam sastra itu sendiri yang mengungkap alasan mengapa pengajaran tentang topik tertentu itu, disampaikan. Tujuan utama dari sebuah pengajaran adalah perubahan perilaku. Tuntutan perubahan inilah yang harus diungkap oleh penafsir.

Menafsirkan cerita contoh dan refleksi sangat mudah. Penafsir dituntut mempelajari pengalaman-pengalaman yang terdapat di dalam cerita tersebut dan menjadikannya teladan di dalam kehidupannya sendiri. Biasanya terdiri dari hasil pengamatan terhadap cara seseorang menjalani hidupnya atau sejarah kehidupan tentang orang tersebut (biografi). Prinsip utama penafsirannya adalah menemukan moral dari cerita dan refleksi yang hendak disampaikan. Moral cerita itu kemudian disusun di dalam prinsip-prinsip praktis yang dapat diterapkan di dalam kehidupan dan prinsip mana yang harus dittolak.

Sastra hikmat yang dinyatakan di dalam bentuk ucapan dapat dimengerti dan ditafsirkan dengan mengikuti alur dialog. Misalnya ucapan-ucapan yang keluar dari mulut Ayub sebagai respon atas penderitaan yang dialaminya. Ucapan-ucapan selalu memiliki pokok utama yang disampaikan di dalam penekanan-penekanan melalui tema, kalimat yang berulang atau kata-kata tertentu yang menonjol. Alur dari sebuah ucapan biasanya dapat dikenali pada bagian pertengahan dan umumnya, di dalam sastra orang Ibrani, munculnya kesimpulan dapat dilihat pada bagian akhir.

Himbauan dan nasihat dapat ditangkap dengan cepat karena menyampaikan pokok tertentu dan sifatnya yang menyempit. Gagasan dan ide yang hendak disampaikan dapat dengan mudah ditangkap melalui kalimat-kalimat sederhana. Sifatnya memberikan input yang bebas diikuti atau ditolak oleh pendengar/pembaca.

Alegori adalah bagian yang paling sulit ditafsirkan di dalam sastra orang Ibrani. Penafsir dituntut menyelami pikiran dan isi kepala penulis. Jika tidak, apa yang ditafsirkan akan berbeda dengan maksud penulis yang sesungguhnya. Hal ini terjadi karena alegori selalu bersifat figuratif, majas dan disampaikan di dalam bahasa yang berbunga. Penafsir perlu mempelajari sejumlah gaya bahasa sastra dan menggunakannya untuk membedah alegori tersebut. Makna disampaikan bukan menggunakan bahasa yang harafiah tetapi melalui retorika bahasa, pilihan kalimat dan contoh yang dipaparkan. Umumnya, sastra orang Ibrani menggunakan majas alegori. Majas Alegori menjelaskan sesuatu dengan gaya bahasa yang bersifat kiasan-kiasan, perumpamaan menggunakan sifat-sifat benda, lambang-lambang tertentu, atau benda-benda lainnya dari alam dan lingkungan. Majas jenis ini membandingkan satu hal atau situasi tertentu dengan obyek lainnya. Karena itu, penafsir harus cermat menangkap ide dan gagasan penulis di balik penggunaan simbol, benda atau perumpamaan tertentu.

Memahami sub kategori dari genre akan menolong penafsir memasuki alam berpikir penulis teks dan menemukan simpul-simpul utama yang membantu mengangkat makna utama di antara sejumlah makna lainnya yang termuat di dalam teks.

\section{Menangkap Gagasan Utama melalui Hermenetik}

Gagasan utama sangat penting di dalam mengangkat makna teks dari sastra hikmat. Disini pentingnya hermenetik sastra. Richard Palmer melihat bahwa sebuah hermenetik di dalam karya sastra bertujuan mengangkat makna dan membawanya ke 
permukaan agar mudah dipahami. Di dalamnya paling tidak terkandung tiga makna dasar yakni mengungkapkan kata-kata, menjelaskan dan menerjemahkan. Ketiganya dapat berpadu dan juga dapat berdiri sendiri secara independen (Palmer, 2016, p. 15). Berdasarkan pendapat Palmer itu dapat dipahami bahwa penafsir sastra hikmat dituntut untuk paling tidak mengungkapkan kata-kata utama dari sastra hikmat tersebut, dan atau menjelaskan maksud daripada teks, dan atau menerjemahkan sebuah teks sastra ke dalam bahasa yang dapat dipahami secara kontemporer. Apalagi sifat sastra orang Ibrani yang identik dengan permainan kata-kata, gagasan utama seringkali tersembunyi di dalam "permainan" tersebut. Hermenetik diperlukan untuk menemukan gagasan tersebut dan menyajikannya kembali dalam kalimat yang dapat dibaca secara harafiah (Schmidt, 2009).

Gagasan utama di dalam teks-teks sastra hikmat di dalam Amsal dapat dilihat pada bagian awal atau akhir teks. Sedangkan di dalam kitab Mazmur gagasan utamanya dapat ditemukan di dalam alur teks dalam pola "pernyataan - kesimpulan". Gagasan di dalam kitab pengkhotbah umumnya muncul di dalam kalimat-kalimat pendahuluan dan kemudian diikuti penjelasan. Sedangkan di dalam kitab Ayub dapat ditemukan di sepanjang dialog dan monolog dari teks.

Gagasan utama akan menolong penafsir: 1) Memilah makna utama daripada makna sampingan; 2) Mengambil kesimpulan dari teks yang penuh dengan permainan kata-kata; 3) Membedakan mana tujuan dan mana penjelasan dari tujuan; 4) Memahmi teks-teks majas alegori; 5) Menyingkirkan pengaruh kalimat-kalimat pelengkap dari kalimat utama teks; 6) Mengambil kesimpulan; 7) Memahami teks secara keseluruhan dan melihat keterkaitan kontekstualnya; 8) Membantu menemukan padanan semantik di bagian lain dari teks.

\section{Melihat Konteks}

Ada dua konteks yang perlu dicermati. Konteks dari teks berupa penempatan kata-kata kunci di dalam rangkaian kalimat dan konteks dari isi teks dengan memperhatikan aspek sejarah, sosial, budaya, antropologi. Perhatikan faktor-faktor yang mempengaruhi makna. Pujian Salomo kepada gadis Sulamite dapat dijadikan contoh.

Kiranya ia mencium aku dengan kecupan! Karena cintamu lebih nikmat dari pada anggur, harum bau minyakmu, bagaikan minyak yang tercurah namamu, oleh sebab itu gadis-gadis cinta kepadamu! Tariklah aku di belakangmu, marilah kita cepat-cepat pergi! Sang raja telah membawa aku ke dalam maligai-maligainya. Kami akan bersorak-sorai dan bergembira karena engkau, kami akan memuji cintamu lebih dari pada anggur! Layaklah mereka cinta kepadamu! Memang hitam aku, tetapi cantik, hai puteri-puteri Yerusalem, seperti kemah orang Kedar, seperti tirai-tirai orang Salma. Janganlah kamu perhatikan bahwa aku hitam, karena terik matahari membakar aku. Putera-putera ibuku marah kepadaku, aku dijadikan mereka penjaga kebunkebun anggur; kebun anggurku sendiri tak kujaga. Ceriterakanlah kepadaku, jantung hatiku, di mana kakanda menggembalakan domba, di mana kakanda membiarkan domba-domba berbaring pada petang hari. Karena mengapa aku akan jadi serupa pengembara dekat kawanankawanan domba teman-temanmu? (Kid. 1:2-7).

Teks di atas menggambarkan ekspresi sukacita atas cinta sekaligus menjelaskan konsep kecantikan sang gadis. Disitu ada kata-kata "hitam" yang jika ditinjau secara historis, gadis yang sedang mendeskripsikan dirinya itu memang kulitnya hitam legam dan bibirnya tebal atau kiasan dari tenda kulit yang hitam legam seperti kemah orang Kedar? (Freeman, 1988, pp. 341-344). Gadis Sulamite di dalam teksteks cinta Kidung Agung menggambarkan dirinya demikian. Analisis lain mengatakan bahwa itu kemungkinan adalah Abhisag, gadis perawan yang menemani masa tua Daud hingga matinya ayah Salomo ini (Gardner, 1995, p. 614).

Konteks sangat penting di dalam menafsirkan sastra hikmat. Penempatan setiap kata atau kalimat di dalam batang tubuh teks selalu memiliki tujuannya sendiri. Penafsir harus memperhatikan dengan cermat setiap konteks dari isi teks. Konteks membuka jalan di dalam memahami teks-teks yang 
panjang dan pernyataan-pernyataan yang sambung menyambung. Konteks memandu penafsir pada makna menurut cara pandang penulisnya. Bagian ini tidak mudah karena alam berpikir dan budaya penulis tidak sama dengan penafsir. Maka melihat keseluruhan maksud penulis di dalam sastra hikmat kadang jauh lebih bermanfaat daripada menelitinya satu persatu.

\section{Perhatikan Gaya Bahasa}

Teks teks sastra orang Ibrani identik dengan penggunaan gaya bahasa. Salah satu yang menonjol menurut Osborne adalah hiperbola. Tujuan tujuan utama dilukiskan melampauhi makna harafiahnya. Osborne mengatakan banyak teks dengan sengaja membesar-besarkan sesuatu dan melazimkan sesuatu. Penafsir harus mendeteksi keberadaan gejala ini di dalam teks (Osborne, 2012, p. 297). Hiperbola yang tidak terdeteksi dapat membelokkan makna teks bahkan mengaburkannya. Oleh sebab itu langkah pertama melihat terlebih dahulu apakah sebuah teks sedang menggambarkan sesuatu dengan lazim atau membesar-besarkannya. Biasanya hiperbola diperlukan untuk memberi penekanan dan penegasan akan maksud penulis kepada pembacanya. Lihat misalnya gambaran yang dipakai penulis pada Mazmur berikut ini: Air mataku berlinang seperti aliran air, karena orang tidak berpegang pada Taurat-Mu (Mzm. 119:136).

Tidak ada aliran air mata dari seseorang yang menangis jatuh dan menjadi aliran air. Ini adalah penggambaran yang hiperbola atau dilebih-

\section{DAFTAR RUJUKAN}

Adamo, D. T. 2015. "Ancient Israelite and African proverbs as advice, reproach, warning, encouragement and explanation." Hts Teologiese Studies-Theological Studies, 71 (3): 01-13.

https://doi.org/10.4102/hts.v71i3.2972

Alexander, T. D., Rosner, B. S., Carson, D. ., \& Goldsworthy, G. 2000. New Dictionary of lebihkan. Selain memberikan penekanan tentang kesedihan, penulis Mazmur ingin membangun ketegasan bahwa Taurat Tuhan itu harus dipegang erat-erat di dalam kondisi apapun. Perhatikan juga teks berikut ini di dalam Ayub 27:20: "Kedahsyatan mengejar dia seperti air bah, pada malam hari ia diterbangkan badai"

Selain hiperbola, beberapa gaya bahasa yang umum dijumpai di dalam kesusasteraan juga muncul di dalam teks teks hikmat orang Ibrani, seperti Metafora, Simili, Sinekdot, Antromorf, Personifikasi, Interogasi, dan Ironi.

\section{KESIMPULAN}

Dengan demikian dapat disimpulkan bahwa pola hermenetik kitab Hikmat Orang Ibrani tidak sama dengan pola hermenetik kitab-kitab lain yang menyusun Perjanjian Lama khususnya dan Perjanjian Baru pada umumnya. Hal ini terjadi karena sifat kesusasteraan naskah dari kitab-kitab tersebut sangat kuat dan berbeda dari naskah-naskah kitab suci lainnya. Kendati dapat menerapkan prinsip umum hermenetik, penafsir dituntut memperhatikan bentuk genre dari kitab sastra tersebut, melihat dengan cermat makna utama, mempelajari berbagai gaya bahasa yang umum dipergunakan di dalam teks dan menempatkannya di dalam konteks yang tepat, sehingga maknanya dapat diangkat ke permukaan. Menafsirkan kitab Hikmat Orang Ibrani membutuhkan seni hermenetik yang komPerjanjian Lamaeks tetapi komprehensif.

Biblical Theology. Nottingham: InterVarsity Press.

Dell, K. J. 2006. The Book of Proverbs in Social and Theological Context. https://doi.org/ 10.1017/CBO9780511488306

Douglas, J. D. 2005. Ensiklopedi Alkitab Masa Kini (1st ed.). Jakarta: Yayasan Bina Kasih / OMF. 
Fox, M. V. 2007. "The Epistemology of the Book of Proverbs." Journal of Biblical Literature , 126.4: 669-684. https://doi.org/10.2307/ 27638461

Freeman, J. M. 1988. The New Manners and Customs of the Bible. Alachua, Florida: Bridge-Lagos.

Gaebelein, F. E. 1991. Psalms, Proverbs, Ecclesiastes, Song of Songs. The Expositor's Bible Commentary with The New International Version of the Holy Bible.

Gardner, P. D. 1995. Encyclopedia of Bible Characters. Michigan: Zondervan.

Gertz, J. C., Berlejung, A., Schmid, K., \& Witte, M. 2017. Purwa Pustaka: Eksplorasi ke dalam Kitab-kitab Perjanjian Lama dan Deuterokanonika. Jakarta: BPK Gunung Mulia.

Goldsworthy, G. 2011. "Wisdom and its Literature in Biblical-Theological Context." The Southern Baptist Journal of Theology, 15: 42-55.

Handbook to the Bible. 2004. Bandung: Kalam Hidup.

Kittel, G. 1971. Theological Dictionary of the New Testament. Grand Rapids, Michigan: Eerdmans.

Klein, W. W., Blomberg, C. L., \& Hubbard, R. L. 2013. Biblical Interpretation 2 Pengantar Tafsiran Alkitab. Malang: Literatur SAAT.

Knut, H. 2010. Prov 26:1-12: A Crash Course on the Hermeneutics of Proverb Reception and a Case Study in Proverb Performance Response. Die Welt Des Orients.

Koller, A. 2012. "Diachronic change and synchronic readings: Midrashim on stative verbs and participles." Journal of Semitic Studies, 57 (2): 265-294. https://doi.org/10.1093/jss/ fgs003

Leeuwen, R. van. 2005. "Wisdom Literature." In K. J. Vannhoozer, C. G. Bartholomew, D. T. Treier, \& Wright (Eds.), Dictionary for Theological Interpretation of the Bible. Grand Rapids, Michigan: Baker Academic.

Murphy, R. E. 1982. The Tree of Life: An Exploration of Biblical Wisdom Literature (2nd ed.). Grand Rapids, Michigan: Eerdmans.

Notarius, T. 2011. "Temporality and Atemporality in the Language of Biblical Poetry." Journal of Semitic Studies, 56 (2): 275-305. https:// doi.org/10.1093/jss/fgr004

Osborne, G. R. 2012. Spiral Hermeneutika. Surabaya: Penerbit Momentum.

Palmer, R. E. 2016. Hermenetika - Teori Baru Mengenai Interpretasi (Edisi III). Yogyakarta: Pustaka Pelajar.

Renn, S. D. 2005. Expository Dictionary of Bible Words. Massachussets: Hendrickson Publisher.

Roberge, J. 2011. What is critical hermeneutics? Thesis Eleven. https://doi.org/10.1177/ 0725513611411682

Schmidt, L. K. 2009. Understanding hermeneutics. Understanding Hermeneutics. https:// doi.org/10.1017/UPO9781844653843

Zabán, B. 2016. "Metaphors in the Wisdom Literature of the Hebrew Bible and Contemporary Art." Religions, 7 (9): 106. https:// doi.org/10.3390/rel709010 